\title{
THE ROLE OF PARENTING IN THE USE OF ETHICAL SOCIAL MEDIA IN KAUMAN VILLAGE, SEDAYU DISTRICT, GRESIK DISTRICT
}

\author{
Akhmad Qomaru Zaman ${ }^{1}$, Suhari $^{2}$, Dwi Retnani Srinarwati ${ }^{3}$, I Made Arsana ${ }^{4}$ \\ 1,2,3,4 Universitas PGRI Adi Buana Surabaya, Surabaya, Indonesia \\ ${ }^{1}$ akhmadqomaruzaman@unipasby.ac.id, ${ }^{2}$ suhari@unipasby.ac.id, \\ 3dwiretnanisrinarwati@unipasby.ac.id, 4imadearsana@unipasby.ac.id
}

\begin{abstract}
The purpose of this community service activity was explained, so that parents, and the community in Kauman Village, Sedayu District, Gresik Regency, had more attention about the importance of assisting children in operating the Mobile Phone (HP), especially in accessing social media. The approach that will be applied in the implementation of this activity is the lecture and simulation methods. The activities that will be carried out are an explanation of the understanding, rules, and dangers that will come if the operation of a child without the assistance and education of a parent, parenting is done by providing how the application of parents who should, in assisting their children to play mobile or social media. From this parenting activity, it can be concluded that there is an increase in the community's understanding of the nature of parenting, and the implementation of parenting, the impacts that can occur. The increase was seen from the average value of the pre-test of $85 \%$, which initially not many participants understood the positive and negative aspects of social media, this means that only $15 \%$ of participants knew the nature of parenting. After taking part in the training in parenting activities, the average post-test score rose to $92 \%$ of participants who understood parenting, and only $8 \%$ were left with low scores.
\end{abstract}

Keywords: parenting, social media, parents

\section{A. Introduction}

For children the family is a place that is considered the most comfortable and safe in themselves, the family has a strategic role in the pattern of children's education. Parenting is an educational effort that can be done by families, their environment by prioritizing learning resources available in the family and community environment in the form of independent learning activities. Good parenting in a family will affect the development of children when they grow up. Riana (2012) said the family has an important role to provide basic education, attitudes, and basic skills, such as religious education, manners, manners, aesthetics, compassion, 
security, the basics for complying with regulations, and instilling habits.

In addition to internal factors within the family, there are also external factors that can affect a child's mental development, one of which is the use of mobile phones. Nowadays cell phones are no longer a luxury item that is only owned by people who work, but almost all people in this era now have cell phones, both men, women, adults, and even children today who have used it. The use of cellphones by children requires parents to be watched because cell phones today function not only as a means of communication but almost all human activities can be done by touching the cell phone.

Families also should teach good values to children using social media through mobile phones. How should the use of mobile phones by the norms that exist in society?

In this regard, all elements have a role in the implementation of moral values towards children in using mobile phones, so this community service will provide material knowledge relating to
"The Role of Parenting in the Use of Ethical Social Media".

\section{B. Method of Implementation}

This training is carried out with the concept of community service activities, the aim is to increase the understanding of parents, teachers, the community as well as the village government so that they can work together in understanding and implementing parenting in their environment.

Methods The approach to be taken to complete this program is the Lecture and simulation methods. In this activity what will be done is an explanation of understanding, rules, and danger that will come if the child is left to play mobile and social media without parental control. The implementation of this activity is divided into 3 (three) stages namely; preparation of activities, implementation of activities, evaluation of overall activities.

\section{Preparation of activities}

The team comes to the location and identifies things that record findings with partners in an activity, including: 
a. observation to partners

b. determine the method of implementation

c. the results of observations, then get a picture of the material that will be delivered.

\section{Implementation of activities}

Place partners in parenting activities in the village of Kauman Sedayu Gresik, before the participant's activity begins, please fill in the pre-test, the purpose of this is to measure the level of understanding of participants regarding parenting. then done by giving a presentation on the material of parenting activities from the resource person. reference from the activity refers to the pretest-posttest design (Sugiyono, 2015).

\section{Evaluation of activities}

In the final stages of the activity, the participants were given a post-test, the purpose of the post-test was to measure the level of understanding of the participants about the parenting activity material.

\section{Result and Discussion}

The purpose of this activity is to instill understanding to parents how important the process of mentoring children is in operating mobile phones and social media. Based on the results of the Pree test with 10 question points given to participants before the activity was obtained data: some of 31 participants from 37 did not understand the true nature of parenting, what are the functions and objectives carried out parenting, meaning $85 \%$ of parenting participants did not understand the importance and procedures parenting. This is by the results of the committee's interview with Mrs. WR "now mas children if not bought a cell phone strike school, almost all small children hold cell phones" one of the male participants sir $\mathrm{SH}$ "well this is good sir, most of the boys play HP as they wish until you forget the time ". it can be concluded that the understanding of the Kauman village community of Sedayu Gresik sub-district on parenting is still lacking.

The parenting given to the Kauman village community of Sedayu District in 
Gresik Regency was carried out using lecture, question, and answer methods and simulations related to the parenting theme. This activity is carried out so that there is two-way communication between the speakers and the participants.

This parenting activity for parents in assisting children with social media provides a new understanding for the residents of Kauman Village, Sedayu District, Gresik Regency. the evidence of the results of this parenting activity can be seen with the post-test scores we gave at the end of the activity showing satisfying results. Of the 37 participants who took part in this activity and we gave a post-test, a total of 32 participants were able to correctly answer the 10 post-test questions that we gave, this means that 92\% of participants understood and understood the nature of parenting from the explanation given by the speakers. the results of our interviews with several participants showed satisfying answers, including the results of our interview with Ms. PA "we are happy with this activity, we know that children are more dangerous now if they are left to play cellphones without control. I experienced this with my child who is a little stubborn when told to study or pray, preferring to play mobile. now we know that good education for children is not enough from school, community families also have a role. I think there is a point too right (PA 04/27/2020) ". Similar to PA's mother, NA's comments also gave a sign of the success of this activity "from now on I will control my child's activities on the cell phone, how he can be technologically literate but still within their age-appropriate limits (NA 27/04 / 2020) ". Mr. BM "we now understand mas the importance of parenting, this turns out to be the responsibility of all of us BM (27/04/2020)".

From the results of the activities carried out, it can be seen that there is a significant level of understanding of parents, in parenting towards assisting their children in using social media.

Parents are the first target in parenting activities, especially about assisting children in using social media. Not only to provide education for their 
children, but parents also have to make an educational contribution for parents and society and children in particular. This effort aims to have good control for children in using social media so that their use is friendly to them, according to their age and psychology. The implementation of the parenting program uses lecture models, simulations with parents and the community providing education to increase their knowledge, especially about the growth and development of children.

\section{Conclusions}

The parenting program was carried out on Monday 27 April 2020 at 08.00, the place for this activity was held at the Polindes of Kauman Village, Sedayu Gresik District. Parenting activity begins with the opening, then the main event, and closing. The core activities of the participants were given 10 test questions about parenting, and at the end of the activity, participants were also given 10 questions that were the same as the posttest. at the end of all activities, an evaluation of the parenting program covers all activities. Learning outcomes from parenting have been conveyed to parents, the community, schools, and the government of Kauman Village. The implementation of this activity is implemented in daily activities within the family environment of village communities in assisting their children with social media.

\section{References}

Direktorat Pembinaan Pendidikan Tenaga Kependidikan dan Ketenagaan Perguruan Tinggi.

Elih Sudiapermana (2012). Pendidikan Keluarga. Bandung: Edukasia Press.

Martuti (2009). Mendirikan dan Mengelola PAUD. Yogyakarta: Kreasi Wacana.

Mukhtar Latif, dkk (2013). Orientasi Baru Pendidikan Anak Usia Dini. Jakarta: Kencana Prenada Media group.

Mulyasa (2012). Manajemen PAUD. Bandung: PT Remaja Rosdakarya.

Peraturan Menteri Pendidikan dan Kebudayaan Republik Indonesia 
Nomor 30 Tahun 2017 tentang

Pelibatan Keluarga Pada

Penyelenggaraan Pendidikan.

Palupi Raraswati. 2016. Makalah

Kebijakan Pembinaaan

Pendidikan Keluarga.

Kementerian Pendidikan dan

Kebudayaan.

Riana Megawangi. 2003. Pendidikan

Karakter untuk Membangun

Masyarakat Madani. IPPK

Indonesia Heritage Foundation.

Shochib, M (2010). Pola Asuh

Orang tua dalam Membantu

Anak Mengembangkan Disiplin

Diri. Jakarta: PT Rineka Cipta.

Sugiyono, P. D. (2015). Metode

penelitian dan pengembangan. Res.

Dev. D, 2015, 39-41

Suyadi dan Maulidya Ulfah (2013).

Konsep Dasar PAUD. Bandung:

PT Remaja Rosdakarya.

Undang-Undang Republik Indonesia

No 20 tahun 2003 tentang Sistem

Pendidikan Nasional 